\section{Gene editing: heed disability views}

CRISPR-Cas9 is a geneediting tool of great potential, although not necessarily from a disability-rights perspective (see D. J. H. Mathews et al. Nature 527, 159-161; 2015). People with disabilities are, in my view, unlikely to be queuing up for genetic modification: their priority is to combat discrimination and prejudice.

To 'fix' a genetic variation that causes a rare disease may seem an obvious act of beneficence. But such intervention assumes that there is robust consensus about the boundaries between normal variation and disability. Contrary to the prevailing assumption, most people with disabilities report a quality of life that is equivalent to that of nondisabled people (G. L. Albrecht and P. J. Devlieger Soc. Sci. Med. 48, 977-988; 1999).

The UK Nuffield Council on Bioethics is deliberating the ethical and social dimensions of CRISPR. International guidelines are urgently needed (Nature 526, 310-311; 2015), and the voices of people living with illness and impairment need to be heard.

Tom Shakespeare University of East Anglia, Norwich, UK. tom.shakespeare@uea.ac.uk

\section{Gene editing: govern ability expectations}

From a disability-rights viewpoint, problems that have dogged the debate on human genetic modification (see go.nature.com/6wb45k) also pervade your curtain-raiser to the US National Academies of Sciences, Engineering and Medicine conference (see D. J.H. Mathews et al. Nature 527, 159-161; 2015). The authors' portrayal of the public as a passive recipient of 'wisdom' from 'experts' goes against healthy discourse on responsible research and governance.

The disability-rights

community has a history of disagreement with such experts (including authorities, scientists and clinicians) over their perception of people with disabilities. This is summarized as 'ableism', a view that disability is an abnormality instead of a feature of human diversity. It can lead to flawed 'solutions' and disempower those affected (see G. Wolbring J. Crit. Anim. Stud. 12, 118-141; 2014).

"It is time to collectively make decisions about the kind of world we want to live in," write Mathews and colleagues. This discussion should include ability expectations and how they should be governed.

Gregor Wolbring University of Calgary, Alberta, Canada. gwolbrin@ucalgary.ca

\section{Gene editing: survey invites opinions}

As the US National Academies of Sciences, Engineering and Medicine summit on the regulation of CRISPR-Cas9 gene-editing tools gets under way, we invite readers to contribute their opinions about this technology and its use to a survey at go.nature.com/eyowaf.

Public engagement in decisions about applications of science and technology that affect society is essential. The summit is, to a degree, modelled on the 1975 Asilomar Conference on the potential biohazards of recombinant DNA (see Nature http://doi.org/899; 2015). It must not make the same mistake of being held behind closed doors.

As one survey contributor remarks, it may be impossible "to get this [CRISPR-Cas9] genie back into the bottle". So when it comes to wishes for the genie, those of both scientists and the public must be considered. Silvia Camporesi, Lara Marks King's College London, UK. silvia.1.camporesi@kcl.ac.uk

\section{Climate change also creates expatriates}

I visited the island of Tuvalu in the Pacific Ocean three decades ago as the environmental assessor for an aid-funded engineering consultancy. Pollution of the freshwater lens and scavenging of protective shoreline coral rubble for construction were problems even then. As you note (see Nature 526, 624-627; 2015), these may drive exodus sooner than rising sea levels.

Nobody likes to be forced out of their home. But small oceanic nations hold a valuable asset: sovereignty. Tuvalu already profits from its own Internet domain (.tv), and sovereign nations have United Nations votes, which are effectively on the market. They can operate attractive tax regimes. They can declare marine reserves and sell rights to fisheries, seabed mining or reef tourism. All of these make money, and it does not have to be divided between many people. They can all be done even if nobody lives there in person. Citizens of such small island nations could thus become well-off expatriates, as well as refugees.

Ralf Buckley Griffith University, Gold Coast, Australia.

r.buckley@griffith.edu.au

\section{Crowdfunding not fit for clinical trials}

Crowdfunding can raise money quickly and with minimal bureaucracy. But it should not be considered as a way to finance clinical trials because of potential ethical implications.

One problem is that funding recipients are not accountable to the public because crowdfunding is unregulated. Another is that there is no setting of research priorities, so crowdfunded clinical trials may not be the most important or widely applicable ones. And media tactics could attract emotional donations, for example by generating false expectations of a 'cure'. Moreover, an inconclusive or negative outcome could erode public trust.

By contrast, the mainstream funding process for clinical trials takes into account disease prevalence, morbidity and mortality, justice and utility. Crowdfunding for clinical trials should be similarly regulated to mitigate its potential risks.

Phaik Yeong Cheah University of Oxford, UK.

phaikyeong@tropmedres.ac

\section{Lessons from EPA on tracking pollutants}

In our opinion, China could learn from the success of the US Environmental Protection Agency (EPA) in providing open-access environmental information to the public. This would enhance the credibility of government decisions.

The EPA's Toxics Release Inventory programme, in partnership with state agencies, collects data from enterprises that must report emissions. It subjects this information to quality-assurance reviews, trends analysis and error correction, as well as making it publicly available. This evaluation of the entire information-flow process increases transparency and accountability.

Using a comparable holistic approach, China's Ministry of Environmental Protection could develop a secure access point for ministries and agencies and a web portal for public access. A designated group might set quality standards and policies for handling such information, akin to the EPA's Office of Environmental Information. Bo Zhang Information Center, Ministry of Environmental Protection, Beijing, China. Wayne S. Davis EPA, Washington DC, USA. zhangbo@mep.gov.cn 